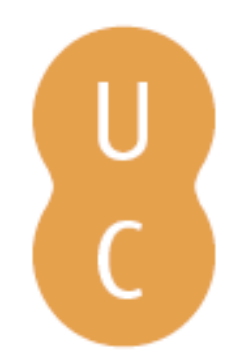

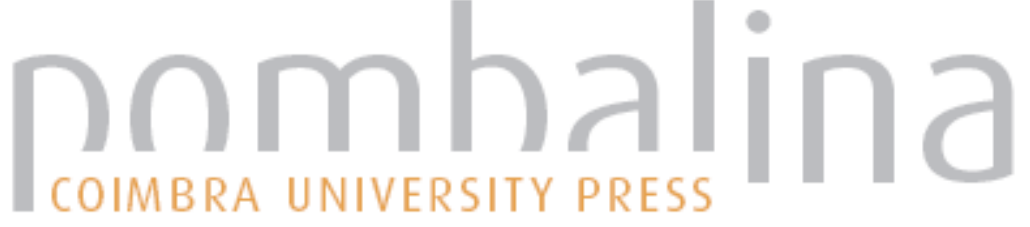

Descobrir com jovens: espaços e paisagens do Truculentus de Plauto

Autor(es): $\quad$ Cordeiro, Adriano Milho

Publicado por: Associação Portuguesa de Estudos Clássicos; Imprensa da

URL

persistente: URI:http://hdl.handle.net/10316.2/31834

DOI: $\quad$ DOI:http://dx.doi.org/10.14195/978-972-98142-2-8_16

Accessed : $\quad$ 26-Apr-2023 09:31:35

A navegação consulta e descarregamento dos títulos inseridos nas Bibliotecas Digitais UC Digitalis, UC Pombalina e UC Impactum, pressupõem a aceitação plena e sem reservas dos Termos e Condições de Uso destas Bibliotecas Digitais, disponíveis em https://digitalis.uc.pt/pt-pt/termos.

Conforme exposto nos referidos Termos e Condições de Uso, o descarregamento de títulos de acesso restrito requer uma licença válida de autorização devendo o utilizador aceder ao(s) documento(s) a partir de um endereço de IP da instituição detentora da supramencionada licença.

Ao utilizador é apenas permitido o descarregamento para uso pessoal, pelo que o emprego do(s) título(s) descarregado(s) para outro fim, designadamente comercial, carece de autorização do respetivo autor ou editor da obra.

Na medida em que todas as obras da UC Digitalis se encontram protegidas pelo Código do Direito de Autor e Direitos Conexos e demais legislação aplicável, toda a cópia, parcial ou total, deste documento, nos casos em que é legalmente admitida, deverá conter ou fazer-se acompanhar por este aviso.

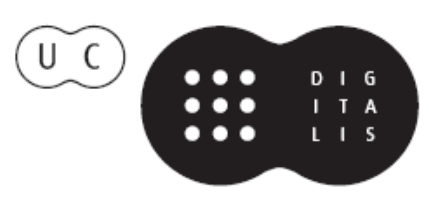




\section{Espaços e Paisagens}

\section{Antiguidade Clássica e Heranças Contemporâneas}

Vol. Il Línguas e Literaturas. Idade Média. Renascimento. Recepção

Francisco de Oliveira, Cláudia Teixeira, Paula Barata Dias (Coords.)

IMPRENSA DA UNIVERSIDADE DE COIMBRA 


\title{
DESCOBRIR COM JOVENS: ESPAÇOS E PAISAGENS DO TRVCVLENTVS DE PLAUTO ${ }^{1}$
}

\author{
Adriano Milho Cordeiro \\ Universidade de Coimbra \\ Centro de Literatura Portuguesa da FLUC
}

\begin{abstract}
Modern Secondary Education only permits us to develop superficial approaches to texts, contexts and landscapes presented by Greek and Latin authors with youngsters. We would like to realise a project that might turn out to be a herculean task: to translate, stage, and perform Plauto's TRVCVLENTVS with teenagers. That is our goal: to discover with youngsters, scenarios and landscapes from Ancient times that are very often contemporary with youngsters.
\end{abstract}

Keywords: learning, pedagogics, Plauto, theatre, Truculentus.

Palavras-chave: ensino, pedagogia, Plauto, teatro, Truculentus.

«Aos homens todos é dado conhecerem-se a si mesmos

e saberem pensar»

Heraclito, séc. VI-V a.C. ${ }^{2}$

\section{Objectivos, condicionalismos, vivências da Escola (pós-moderna)}

Apesar dos amotinados tempos que os Ensinos Básico e Secundário vivem hoje, em Portugal, ainda nos sobra uma mão cheia de alento para trabalhar e encenar com discentes, particularmente do Secundário, peças de autores da Antiguidade Clássica.

Focalizando:o principalobjectivo do Projecto que ora apresentamosé encenar com discentes do Ensino Secundário o Truculentus de Plauto. Necessitamos de alunos com alguma maturidade psicológica e alguma experiência de palco. Como conseguir matéria humana para concretizar tal aç̧ão?! A sementeira fazse no 3. ${ }^{\circ}$ Ciclo do Ensino Básico, quer nas aulas da disciplina de Teatro, quer

\footnotetext{
${ }^{1}$ Parafraseando Augusto Cury dedico este singelos pensamentos a todos

«[...] aqueles que procuraram não ser vítimas do rolo compressor da história, que procuraram dar um sentido mais nobre à sua vida e investir em sabedoria na sinuosa, turbulenta e bela existência humana.»

Augusto Cury ( $\left.{ }^{5} 2007\right)$, O Mestre dos Mestres, São Paulo, p. 5.

${ }^{2}$ Tradução de M. H. da Rocha Pereira ( $\left.{ }^{9} 2005\right)$, Hélade - Antologia da Cultura Grega. Porto, Edições Asa, p. 155.
} 
no mais ou menos (in)formal Clube de Teatro. Segundo Bartolomeu Valente deve-se «reanimar, mobilizar, interessar, porventura entusiasmar a comunidade educativa, de tal modo que devenha matriz de cultura viva e revitalizante [...] no âmbito da literatura [...] ou no da descoberta ou invento científicotecnológico [...] ou no das disciplinas críticas e qualitativas [...] história e [...] e filosofia ${ }^{3} . »$ Procuramos desinfantilizar paulatinamente para uma vida outra $^{4}$, a partir da componente educativa, legalmente institucionalizada, adaptada a cada caso e circunstância sempre «em prol da festa da cultura-vida, do desvendamento pessoal e comunitário, dentro e fora dos muros escolares ${ }^{5}$.» Segundo Yves Bertrand \& Paul Valois:

«As orientaçôes da organização educativa dependem das orientaçôes definidas pelo campo paradigmático. Estas orientaçôes são, em seguida, traduzidas em normas e leis pelo campo politico que, desta forma, regula a organização educativa. [...] No entanto, a organização educativa poderá também propor novos paradigmas socioculturais que designamos por contraparadigmas, uma vez que se opõem e procuram substituir um paradigma dominante. $[\ldots]^{6}$,

Em Outubro de 2005, numa conferência por nós proferida em Braga no V Congresso da $\mathrm{APEC}^{7}$, afirmámos: «Nas últimas décadas, quer o ensino da Língua e da Literatura Portuguesa quer a leccionação das disciplinas de Latim e Grego têm vindo a ser preteridas em relação a áreas curriculares que deformam $\mathrm{e}$, [alegadamente e de forma genérica] em nada contribuem para inteirar os discentes dos Ensinos Básico e Secundário nos saberes das ciências sociais e humanas [...]. A Expressão Dramática e o Teatro como áreas alternativas e possíveis nos actuais currículos, permitem a docentes e alunos, rebuscar n' "As Máscaras das Memórias Presentes e Passadas", ensinamentos, matérias

${ }^{3}$ Cf. Bartolomeu Valente (1998), Por uma Escola-Projecto. Lisboa, Livros Horizonte, p. 23.

${ }^{4}$ Idem, ibidem, p. 71.

${ }^{5}$ Ibidem.

${ }^{6}$ Yves Bertrand \& Paul Valois (1994), Paradigmas Educacionais - Escola e Sociedades. Lisboa, Instituto Piaget, pp. 30-31. Na contra capa desta obra diz-se algo de muito significativo: «A educação está unida à sociedade por laços indissociáveis. Determinado por orientações de natureza social, o sistema educativo tende a reproduzir e promover, modelos caros ao sistema social que o informa. Tal não significa porém, que a sua função criadora ou regeneradora deva ser ignorada ou negligenciada. Para os autores desta obra é esse, aliás, o papel essencial da educação. Esta obra apresenta uma panorâmica das diferentes teorias da educação, contrapondo-as aos vários tipos de organização social. Tendo em conta a alteração das relações entre a escola e o tecido social. Yves Bertrand e Paul Valois propõem uma alternativa mais ecológica e espiritual que favoreça a criação de uma comunidade educativa assente na valorização e no respeito pelas diferenças e liberdades individuais».

${ }^{7}$ Adriano Milho Cordeiro (2006), «As Máscaras da Memória. "O Nome da Rosa” no Convento de Cristo em Tomar - o teatro como factor de revisitação e perenidade da antiguidade da antiguidade clássica» in A Antiguidade Clássica e nós: Herança e identidade cultural. Braga, Universidade do Minho, Centro de Estudos Humanísticos, 567-573. 
atitudes, reflexões e estímulos que os novos tempos pretendem trazer, sem que o tenham assente ${ }^{8} . »$

Numa entrevista à revista Visão ${ }^{9}$, o escritor, professor, ensaísta Miguel Real, pseudónimo de Luís Martins, especialista em Cultura e Estudos Portugueses, afirma que «há um apagamento total da espiritualidade que Portugal desenvolveu em oito séculos. [...] A escola fomenta uma competição técnica feroz, promove o individualismo e renega o ensino dos valores da partilha, da honra, da lealdade, da motivação para as artes e a cultura. Hoje, nenhum aluno estuda para se motivar, estuda para médias e metas. A escola está totalmente submetida ao mercado. Já não interessa formar cidadãos humanistas, responsáveis e intervenientes. $\mathrm{O}$ fim das pessoas é o dinheiro, sempre. Portugal cheira alarvemente a dinheiro. [...] - [Esperava-se mais dos intelectuais:] - [...] Eduardo Lourenço falou dos perigos de estarmos a criar uma "Disneylândia cultural", ou seja, a reduzir a cultura portuguesa e europeia ao formato Hollywood. Hoje, é impossível estudar Grego no liceu. E é dificílimo estudar Latim. Pergunta-se: para que é que isso serve? Pois, mas as coisas que ficam na História são as que nos parecem inúteis no tempo em que foram feitas. O Camões recebeu uma tença anual de 15 mil réis para publicar Os Lusíadas. A viúva do João de Barros, que era feitor da Casa da India, recebeu 150 mil. Quem se lembra da viúva?»

O que pretendemos é muito simples. Já há muito que fizemos o diagnóstico à situação angustiante e sem sentido que se vive em Portugal, acerca de década e meia ou mais, pelo menos: «A missão da Escola democrática não pode estar arreigada às pressões conjunturais e tecnocraticamente eficazes em termos de destruição educativa ${ }^{10}$. Já em 1979 o filósofo francês Jean-François Lyotard

${ }^{8}$ No artigo, «Ainda a proposta de revisão curricular do ensino secundário e os novos programas de Latim e Grego» Boletim de Estudos Clássicos, 2002, 37, 165-169, escrito nos idos de 2002, indignados com o decorrer dos acontecimentos e com os perversos sinais dos tempos, nos dávamos conta da situação iníqua, descabida e altamente lesiva para os interesses educacionais em Portugal, nomeadamente no que diz respeito ao quase desaparecimento do ensino da Literatura Portuguesa, do Latim e do Grego. A reparação legislativa de Julho de 2007 (oficializada depois de uma grande parte das matrículas para o ano lectivo de 2007/2008, terem já sido efectuadas, em virtude de estarmos, então, quase nos finais de Julho; e acrescente-se que o mesmo DecretoLei introduziu mudanças de monta nos cursos e horários dos alunos) não desagrava o erro, pois, estas disciplinas continuam ostracizadas pelo poder instituído. A criação do Curso CientíficoHumanístico de Línguas e Humanidades resultante da junção do agrupamento G5 - Curso Ciências Sociais e Humanas e do agrupamento G7 - Curso Línguas e Literaturas, contemplando a oferta de disciplinas da componente de formação específica dos dois cursos é uma operação de mera cosmética. Cf. Decreto-Lei n. ${ }^{\circ} 272 / 2007$, publicado no Diário da República, 1. ${ }^{\text {a Série, }}$ n. 143 , de 26 de Julho, que altera as matrizes dos currículos dos cursos científico-humanísticos do Ensino Secundário.

${ }^{9}$ Cf. Visão, n.o 784, 13 de Março de 2008, pp. 54-58.

${ }^{10}$ José Augusto Cardoso Bernardes (2005), A Literatura no Ensino Secundário - Outros Caminhos. Porto, Areal Editores, pp. 47-48. Na nossa opinião, o conhecimento não pode ser reduzido apenas ao tão badalado "saber-fazer", sabendo quem está no terreno que os alunos terminam o $12 .^{\circ}$ ano a "saber-fazer" muito pouco, ou quase nada, ou como diz sabiamente o nosso povo: com uma mão cheia de nada e outra de coisa nenhuma. É nosso dever avisar que 
alertava para a desumanizada sociedade em que vivemos, a caminho do inumano, a deslegitimação das metanarrativas através de jogos de linguagem subtis $^{11}$, apoiados numa nova retórica, onde só o que é performativo ${ }^{12}$, é válido e passível de ser ensinável nas Escolas ${ }^{13}$. «A transmissão de saberes já não surge destinada a formar uma élite capaz de guiar a nação na sua emancipação, antes fornece ao sistema os jogadores capazes de assegurar convenientemente o seu papel nos lugares pragmáticos de que as instituições necessitam ${ }^{14}$.» «Os jogos de linguagem serão então jogos de informação completa no momento considerado ${ }^{15}$.»

Padecemos hoje de sisudas complicações ao nível da nossa identidade dilacerada por penetrantes metamorfoses pós-moderna ${ }^{16}$. Não desejamos de forma alguma como João Lobo Antunes afirmou recentemente, despejar sobre os alunos «o mais corrosivo dos ácidos - o do aborrecimento ${ }^{17}$.» As tarefas são

são muito poucos, apesar de hercúleos esforços, os alunos que terminam o $12 .^{\circ}$ ano. Será que as tão propaladas Novas Oportunidades, tão sublinhadas e propagandeadas, sobretudo de há três anos para cá, elevaram o nível de literacia do povo português?! Escusamo-nos neste momento e dada à natureza deste artigo de tecer quaisquer comentários em relação ao forjado e aparente sucesso apresentado e sufragado pelos dados estatísticos relativos ao Ensino Básico e Secundário em Portugal. A propósito será que a aplicação e ensino da tão propagada TLEBS (Terminologia Linguística para os Ensinos Básico e Secundário) trará algo de positivo para o ensino do Português?! Inequivocamente trará isso sim, é mais insucesso. Cf. http://www.ipetitions.com/ petition/contratlebs/

${ }^{11}$ A propósito da expressão e conceito - jogos de linguagem - veja-se Ludwig Wittgenstein (1989), Fichas (Zettel). Lisboa, Edições 70, p. 32.

${ }^{12}$ Performativo no texto acima escrito apresenta um sentido relacionado com lucro monetário ou com tudo o que o possa fazer acontecer. Ainda que retoricamente disfarcem os seus "jogos", os trilhos actuais ligados ao poder, ao mercado e ao Ensino transmitem-nos uma ideia bem clara e eticamente dissimulada: só o que é vendável tem sucesso e deve ser promovido no Ensino!... O resto deve ser relegado para segundo plano.

${ }^{13}$ Cf. Jean-François Lyotard ( $\left.{ }^{3} 2003\right)$, A condição Pós-moderma. Lisboa, trad. José Navarro, revista e apresentada por José Bragança de Miranda, Gradiva, pp. 12 e ss.

${ }^{14}$ Idem, ibidem, p. 99.

${ }^{15}$ Idem, pp. 132-133.

16 Segundo http://pt.wikipedia.org/wiki/Jean-Fran\%C3\%A7ois_Lyotard, «Jean-François Lyotard (Versalhes, 10 de agosto de 1924 - Paris, 21 de abril de 1998) foi um filósofo francês, foi um dos mais importantes pensadores na discussão sobre a pós-modernidade. Autor dos livros A Fenomenologia, A Condição Pós-Moderna e O Inumano. No seu livro A Condição Pós-Moderna (1979), utiliza o conceito de "jogos de linguagem", originalmente desenvolvido por Ludwig Wittgenstein, e refere-se a uma agonística entre esses jogos - característica da experiência da pós-modernidade, assim como a fragmentação e multiplicação de centros e a complexidade das relações sociais dos sujeitos. O título deste que é seu trabalho mais citado e conhecido, era originalmente $\mathrm{O}$ pós-moderno, tendo sido modificado para $A$ Condição Pós-Moderna para expressar uma condição de vivência. O Pós-Moderno seria “o estado da cultura, depois de transformações súbitas nas regras dos jogos da ciência, da literatura e das artes, a partir do século XIX. [...] Simplificando ao máximo, 'pós-moderno’ é a incredulidade em relação às metanarrativas.” Segundo Lyotard, "não podemos mais recorrer à grande narrativa - não podemos nos apoiar na dialética do espírito nem mesmo na emancipação da humanidade para validar o discurso científico pósmoderno".»

${ }^{17}$ Cf. Visão, n. ${ }^{\text {786, }} 27$ de Março de 2008, pp. 106-110. 
tormentosas, porém mescladas com afeição, prazer, dedicação hão-de produzir alguns bons frutos com o tempo, cidadãos conscientes, plenos na sua livre modulação do imaginário prontos para viver em alteridade com posturas, valores e práticas em harmónica relatividade com todas as épocas e situações. Também a missão da Universidade tem sido questionada ${ }^{18}$. A reinvenção é também uma das características da pós-modernidade ${ }^{19}$ ou da hipermordenidade ${ }^{20}$. Como afirmava Lyotard o realismo em que mergulhámos,

"seja lá o que for" é o do dinheiro: faltando critérios estéticos, continua a ser possivel e útil medir o valor das obras em função do lucro que se pode obter com elas. Este realismo acomodase a todas as tendências, como o capital a todas as "necessidades", desde que as tendências e as necessidades tenham poder de compra. [...] A pesquisa artística ou literária está duplamente ameaçada: pela "politica cultural" uma vez, e pelo mercado da arte e do livro outra [... $]^{21}$."

A formação para os valores continua hoje, na Escola, a ter uma pertinência indispensável e a apresentar-se como um elemento determinante da cultura geral da nossa época e porque inerente ao Homem, de todas as épocas. O

${ }^{18}$ Cite-se, e apenas como exemplo bibliográfico, sobre a sobrevivência e o papel das Universidades as seguintes obras: Jacques Derrida (2003), A Universidade sem Condição. Coimbra, Angelus Novus Editora; José Ortega y Gasset (2003), Missão da Universidade e outros textos. Coimbra, Angelus Novus Editora; Bill Readings (2003), A Universidade em Ruinas. Coimbra, Angelus Novus Editora.

19 Segundo http://pt.wikipedia.org/wiki/P\%C3\%B3s-moderno, «Pós-modernidade é a condição sócio-cultural e estética do capitalismo contemporâneo, também denominado pósindustrial ou financeiro. $\mathrm{O}$ uso do termo se tornou corrente, embora haja controvérsias quanto ao seu significado e pertinência. Tais controvérsias possivelmente resultam da dificuldade de se examinarem processos em curso com suficiente distanciamento e, principalmente, de se perceber com clareza os limites ou os sinais de ruptura nesses processos. Segundo um dos pioneiros no emprego do termo, o francês François Lyotard, a "condição pós-moderna" caracteriza-se pelo fim das metanarrativas. Os grandes esquemas explicativos teriam caído em descrédito e não haveria mais "garantias", posto que mesmo a "ciência" já não poderia ser considerada como a fonte da verdade. [...] O filósofo francês Gilles Lipovetsky prefere o termo "hipermodernidade", por considerar não ter havido de fato uma ruptura com os tempos modernos - como o prefixo "pós" dá a entender. Segundo Lipovetsky, os tempos atuais são "modernos", com uma exarcebação de certas características das sociedades modernas, tais como o individualismo, o consumismo, a ética hedonista, a fragmentação do tempo e do espaço. Já o filósofo alemão Jürgen Habermas relaciona o conceito de Pós-Modernidade a tendências políticas e culturais neoconservadoras, determinadas a combater os ideais iluministas.»

${ }^{20}$ Veja-se ainda sobre este assunto: http://pt.wikipedia.org/wiki/Hipermodernidade «Hipermodernidade é o termo criado pelo filósofo francês Gilles Lipovetsky para delimitar o momento actual da sociedade humana. O termo "hiper" é utilizado em referência a uma exacerbação dos valores criados na Modernidade, atualmente elevados de forma exponencial. A Hipermodernidade é caracterizada por uma cultura do excesso, do sempre mais. Todas as coisas se tornam intensas e urgentes. [...] O termo Hipermodernidade como idéia de exacerbação da Modernidade surgiu em meados da década de 70 e ganhou destaque em 2004 graças ao estudo de autores franceses e ao livro "Os tempos hipermodernos" do próprio Lipovetsky.»

${ }^{21}$ Cf. Jean-François Lyotard ( $\left.{ }^{2} 1993\right)$, O Pós-moderno Explicado às Crianças. Lisboa, trad. Tereza Coelho, Publicações Dom Quixote, pp. 19-20. 
objectivo principal é propiciar aos jovens o acesso a paradigmas culturais, cívicos e ético-morais que lhes sustentem: 1) as posturas para consigo mesmos, 2) os usos e os procedimentos para com os outros e 3) as atitudes ante a natureza e o cosmos ${ }^{22}$.

Se as Ciências Humanas conseguirão sobreviver na Universidade, ou no Ensino Secundário, disso não temos dúvidas. Por outro lado, a descentralização que preferimos apelidar antes de fragmentação pósmoderna ${ }^{23}$ exige quer por parte das Escolas a nível local, quer por parte de poderosos movimentos e facções autárquicas, programas culturais com alguma clarividência. Como já acima referimos, não é por acaso que o Cine-Teatro Virgínia e indirectamente a Câmara Municipal de Torres Novas possam vir a apoiar um projecto como é o nosso, o de pôr em cena o Truculentus de Plauto ${ }^{24}$. Temos então boas oportunidades para combater o neo-historismo também apelidado de não-historicismo, pois o estilo e as matérias do Truculentus de Plauto são inconfundíveis, porque são de todos os tempos, são o âmago da essência humana ${ }^{25}$. A entropia que se apregoa na

${ }^{22}$ Carlos Assunção \& José Esteves Rei (1999), Educar para os Valores. Lisboa, Ministério da Educação, Departamento do Ensino Secundário, p. 9.

23 Cf. Segundo o sítio http://pt.shvoong.com/social-sciences/1649447condi\%C3\%A7\%C3\%A3o-p\%C3\%B3s-moderna/ a pós-modernidade pode caracterizar-se da seguinte forma: «Não mais importa que se utilize o saber na construção de teorias especulativas sobre a condição da humanidade, sobre a finalidade da filosofia, ou sobre questões abstractas, que não tratem directamente de produção de técnica e produtos. Neste momento o saber adquire função estritamente técnica. A formulação de teorias sobre produtividade e tecnologias é o único saber importante, e este extracto já está determinado no início da década de setenta. Já se pode observar a queda das perspectivas de teorias sobre a humanidade como um todo, de unificação desta, ou mesmo da famigerada liberdade mundial, do projecto iluminista. Não há mais espaço para a especulação metafísica e, assim, não há mais que se discutir sobre a liberdade da humanidade. Muito menos, agora, ela pode ser vista como um todo; é o que se chama de fragmentação. [...] Lyotard, em sua crítica à pós-modernidade, está envolvido em todas estas questões, mas enfoca a questão do saber. Como a alienação da crítica ao consumo, vinculado o consumidor à ideologia deste consumo, está o ser pensante e com ele o pensamento. A ideologia da tecnologia, caracterizada por formas de aperfeiçoamento eterno e constante, dão a impressão ao homem de que o saber técnico é a realização da humanidade. Seja nos lares comuns, frente à televisão, o computador, mas principalmente nos âmbitos universitários o saber se instala como fonte de produção de tecnologia. Esta tecnologia tem a função de atender a demanda de produtos, máquinas e armas a serem produzidas. Ele chama isto de deslegitimação. O saber das instituições está vinculado a uma nova forma de saber: o optimizatório.»

${ }^{24}$ Áté porque o próprio eclectismo actual, sobre o qual Jean-François Lyotard reflectiu e ainda o facto de na condição pós moderna não haver previsão de todo, mas de fragmentações grupais, preocupadas com a sua segurança, faz com que nós e as facções onde nos integramos preocupemos e reajamos de forma enérgica. Bem observadas as modas, na pós-modernidade os artistas até têm maiores oportunidades para comunicar. Pouco nos importa que a quantidade incalculável de tendências e linguagens tornem impossível a unicidade formal. E depois há sempre grupos que fartos do mesmo em toda a parte, de similaridades estéticas e da premente homogeneização das relações de produção e dos hábitos de consumo exijam produtos culturais diferentes.»

${ }^{25}$ Diz-nos George Steiner (2007), A Ideia de Europa, Lisboa, Gradiva, pp. 35-36, relativamente à longa caminhada da história europeia afirma o seguinte: «[...] Um europeu culto é 
Pós-Modernidade diz respeito ao fim da interdição, à aceitação de todo e qualquer produto, pois, toda produção é considerada mercadoria que há-de ser regulada pelo mercado. Porém, já Gil Vicente no caso português observava no Auto da Feira que tudo era comerciável. Também João de Barros na sua Ropicapnefma ou Mercadoria Espiritual (1532) aborda o assunto, embora de uma outra forma.

Yves Bertrand \& Paul Valois dizem-nos que

\begin{abstract}
«A organização educativa que opta por uma aç̧ão crítica encontra-se à margem da cultura dominante. Além disso, um dominio total de um paradimgma sociocultural é absolutamente inconcebivel. Há sempre um contraparadigma. Gersick (1991) afirma que a história das organizaçôes mostra que a mudança revolucionária não pode ser contrariada constantemente e que, mais cedo ou mais tarde, sucederá a um período de estabilidade. [...] Ferguson (1987) lembranos que as modificações radicais, que se anunciam, residem, na sua opinião, numa concertação, ou seja, numa "conspiração" de pessoas que propõem novas opçôes educativas e societais ${ }^{26}$."
\end{abstract}

\title{
2. Pôr em cena, na Escola, O Truculentus de Plauto: à partida uma opção com sucesso
}

Confrontados com espaços e paisagens de outras eras, confrontados com um argumento tão actual, os nossos discentes até se mostram interessados em fazer algo.

«Uma cortesã finória, Fronésio, explora sem qualquer pudor, por todos os meios, os seus três amantes (um ateniense, Diniarco, o camponês Estrábax, e um soldado babilónio, Estrastófanes.

apanhado na teia de um in memoriam simultaneamente luminoso e sufocante. É precisamente esta teia que a América do Norte repudia. A sua ideologia tem sido a do nascer do Sol e da futuridade. Ao declarar que "História é palavreado inútil", Henry Ford forneceu a senha de acesso à amnésia criativa, a um poder de esquecimento que subjaz a demanda pragmática da utopia. O mais elegante dos novos edifícios possui um factor de obsolescência de uns quarenta anos. A guerra do Vietname lançou uma sombra quase digna do velho mundo, o onze de Setembro provocou um estremecimento, um memento mori na psique americana. Mas estes motivos excepcionais e quase certamente transitórios. As recordações mais fortes na sensibilidade e idioma americanos são as da promessa, daquele contrato com horizontes vastos que fez do movimento em direç̧ão ao Oeste, e, rapidamente, da viagem planetária, um novo Éden. Daí o crescente mal-estar sentido em relação ao mero pensamento de transformar em memorial a destruição (terá vida breve) do World Trade Center. Entretanto, um mausoléu deliberadamente brutal e, em minha opinião despropositado, sepultará um espaço central de Berlim. Quão mais verdadeiros ao manifesto de Jesus: «deixai os mortos enterrar os seus mortos», são os homens e as mulheres do Novo Mundo! O peso ambíguo do tempo verbal pretérito na ideia e substância da Europa deriva de uma dualidade primordial - que constitui o meu quarto axioma: a herança dupla de Atenas e Jerusalém. Esta relação, simultaneamente conflituosa e sincrética, ocopou o debate teológico, filosófico e político dese os Doutores da Igreja a Leon Chestov, de Pascal a Leo Strauss. O topos é Agora tão rico e premente como sempre. Ser europeu é tentar negociar, moralmente, intelectualmente e existencialmente, os ideias, afirmações, praxis rivais da cidade de Sócrates e da cidade de Isaías. [...].

${ }^{26}$ Yves Bertrand \& Paul Valois (1994), Paradigmas Educacionais - Escola e Sociedades. Lisboa, Instituto Piaget, pp. 32-33. 
Estrábax tinha um escravo, Truculento, verdadeiramente fiel ao seu nome (que exprime rudeza, mau carácter), que costuma travar memoráveis discussöes com Astáfio, a escrava de Fronésio, em nada indigna da sua patroa. Para continuar a merecer a atenção do soldado, Fronésio forja um engano e convence a sua vítima de ter uma criança dele. Por fim, o engano vem a ser descoberto, e um dos outros dois jovens, Diniarco, acaba por casar com a verdadeira mãe da criança, uma mulher de condição livre que ele mesmo tinha seduzido ${ }^{27}$.»

Censurou-se muitas vezes ao Truculento a sua imoralidade; não sem razão. É certo que Fronésio é a mais libertina e a mais cúpida das cortesãs de Plauto; o seu cinismo só é ultrapassado pelo de Diniarco. Há poucos exemplos de um amante a quem a paixão tenha também pervertido completamente. Todos os actos sexuais que pede a Fronésio, ele realiza-os alegremente ultrapassando todas as suas exigências. Cegueira do amor, admitamos; mas como desculpar então a sua conduta perante a filha de Cálicles, esta violação, este abandono? Sem dúvida ele "dará reparação" pelo casamento, mas sem renunciar a Fronésio, da qual continuará a ser, depois como antes, o amante, o conselheiro, o servidor e o cúmplice. Solteiro, ele é digno de dó; casado, ele tornar-se-á odioso. Alguma indulgência que se possa ter pelas estroinices dos jovens, tem-se dificuldade em tolerar Diniarco e sente-se na leitura da peça uma impressão de mal-estar, mesmo de repugnância. É preciso acreditar que o público romano não era tão difícil e depois Diniarco era apenas um grego. Seria necessário formalizar-se com os costumes e o carácter dum Graeculus esuriens ${ }^{28}$ ?»

Algumas boas sementes andam por aí, germinando por vezes, em obscuros solos, esfumando universos oníricos que devem ser bem consubstanciados pelos educadores. Uma seara maior falta advir. $\mathrm{Na}$ verdade, o quê e como intervir junto dos jovens requer criatividade, imaginação e logicamente um mínimo de conhecimento das circunstâncias e conjunturas em que as experiências em mente podem resultar. Por muito entusiastas e empenhados que sejamos, nem sempre se consegue com facilidade - e refira-se estamos a ter em linha de conta todas as partes envolvidas - informações bastantes, constatação de competências e sensibilidades apuradas para pôr em cena com jovens hodiernos e, nossos discípulos, uma peça como o Truculentus de Plauto.

Conseguir alunos para pequenas representações não é difícil. Porém, pensar em encenar pela primeira vez em Língua Portuguesa, ao que julgamos, o Brutamontes do Sarsinate não é tarefa dócil. Para que tudo se torne viável tem de existir primeiro todo um trabalho de tradução e perscrutação sobre a peça e

${ }^{27}$ M. Citroni et al. (2006), Literatura de Roma Antiga. Lisboa, Fundação Calouste Gulbenkian, p. 110 .

${ }^{28}$ Cf. Plaute, Comédies (1961), Texte établi et traduit par Alfred Ernout, Tomo VII, 2 ème éd. rev. et corr. Paris, Les Belles Lettres, pp. 92-95. 
ao mesmo tempo ensaiar experiências teatrais com os alunos. Ainda assim, esta é labuta exclusivamente do docente.

Infelizmente, a temática da peça plautina em causa, é duma actualidade lancinante e atroz. Talvez seja esse o motivo condutor que entusiasma os nossos aprendizes de sonhos, pois que os mesmos, ou similares assuntos desenvolvidos no Truculentus são hoje triviais, aos ouvidos ou à vista dos homens e das sociedades, todavia, conteúdo importante nos diversos meios de comunicação social.

Em educação nada ocorre por obra de magia e as maturações brotam de duráveis paciências e laboriosas indagações. $\mathrm{O}$ Teatro pode ser para os jovens de hoje o que foram as parábolas para os cristãos - sementes para germinar e frutificar. Não há dúvida de que vivemos num mundo tecnicizante que tende reduzir tudo a números. Por vezes e, como tão bem opina Bartolomeu Valente:
"[...] o problema é, pois, como reanimar, mobilizar, interessar, porventura entusiasmar a comunidade educativa, de tal modo que devenha matriz de cultura de cultura viva e revitalizante, ressuscitando o pulsar das criações presentes como dos tempos idos, em lugar de recoveira tanto dos sentidos de antanho como dos actuais, no âmbito da literatura (não há poema, conto nem romance que aguente o agredir das análises, obrigatoriedadades e avaliaçôes legais dos alunos) ou no da descoberta ou invento científico-tecnológico (mesmo os laboratórios, oficinas e trabalhos de campo se tornam entediantes no contexto impositivo e pré-programado actual) ou no das disciplinas críticas e qualitativas (a história e afins [...] a filosofia [...]”

Por termos vivido experiências anteriores algo semelhantes, ainda que de menor projecção lançamo-nos agora na tentativa de pôr em cena uma obra. Podemos contar à partida e para já com dois apoios institucionais importantes: a Escola Secundária de Maria Lamas, o Teatro Virgínia de Torres Novas e vários Professores do Instituto de Estudos Clássicos da Faculdade de Letras da Universidade de Coimbra. Sei que os discentes têm disponibilidade interior para prosseguir com a hercúlea tarefa. O problema maior prende-se com o tempo disponível por parte dos discentes. Ajustar um ou dois tempos por semana que permitam que a encenação possa ser vivida por todos e ao mesmo tempo é tarefa árdua e quase impossível ${ }^{29}$.

$\mathrm{O}$ professor deve de preparar os alunos para que estes tenham aproveitamento na Área Projecto no final do $12 .^{\circ}$ ano, pois tal como noutras disciplinas, também a Área Projecto tem diferentes níveis e patamares de desenvolvimento. «Concluem o nível secundário de educação os alunos que obtenham aprovação em todas as disciplinas e áreas não disciplinares do plano de estudos de respectivo curso.» (Art. ${ }^{\circ} 14 .^{\circ}$ do Decreto-Lei n. ${ }^{\circ} 74 / 2004^{30}$.)

${ }^{29}$ Estamos a optar muitas das vezes por encenações parciais, pois os condicionalismos são muitos e prendem-se sobretudo com a forma como o curriculum escolar é plasmado em termos de horário.

${ }^{30}$ Cf. Manuela Matos Monteiro (2007), Área de Projecto. Porto, Porto Editora, p. 13 
$\mathrm{Na}$ verdade o Homem deve revelar-se ao longo da vida como «um animal com memória e projecto ${ }^{31}$.»

«É preciso adaptar de acordo com as características de cada aluno, de acordo com as suas necessidades. É premente que exista flexibilidade para cada escola poder dar aos seus alunos os ensinamentos que os motivem, que lhes proporcionem sucesso, que desenvolvam as suas capacidades e enriqueçam os seus conhecimentos. Tudo isto é possível se alterarmos as nossas estratégias e se repensarmos a forma de avaliar ${ }^{32}$.»

O teatro pode ter domínio terapêutico, pois permite aos adolescentes libertarem-se da sua pessoalidade e viver o gosto de uma existência nova não podendo ser considerado como um luxo ${ }^{33}$. O teatro é a mais completa e acabada maneira de educar e deleitar sintetizando um conjunto muito importante de actividades culturais, recreativas e artísticas ${ }^{34}$.

Opina e muito bem Glória Bastos que «[...] é através das personagens que o leitor contacta não só com as peripécias da fábula, como referimos, mas ainda com diversas concepções da realidade, consoante o ponto de vista expresso. A função de tais relatos é assim também interpretativa, pois não se trata de um narrador omnisciente que perspective a narrativa de uma forma globalizante, mas de diferentes personagens com leituras diversas do mundo ${ }^{35}$.»

Parafraseando Tito Agra Amorim: «É óbvio também que muita da informação que adquirem os nossos jovens de hoje é bebida fora da escola. Bom ou mau? Para mim apenas motivo para reflexão, e alimento para dar consistência às actividades que me têm permitido uma maior aproximação com os jovens e a partilha de uma praxis que valoriza as componentes humanas e vivenciais e que permite solidificar relações, fazer nascer curiosidades e viver mais intensamente um tempo de incertezas, de encontros e de desencontros ${ }^{36}$."

Reconstruamos assim uma paideia nova assente na motivação de reler os clássicos e descobrir neles coisas novas neste inimaginável mundo novo, rodeados de tecnologias e todavia ao mesmo tempo de saberes antigos que

${ }^{31}$ Cf. André Lichnerowicz citado por Diana Felizardo (2004), op. cit., p. 7.

${ }^{32}$ Diana Felizardo (2004), op. cit. p. 5.

${ }^{33}$ A este respeito afirma Louis Porcher (1982), Educação Artística - Luxo ou Necessidade. São Paulo, Editora Afiliada, p. 9: «Aqueles que identificam a Educação Artística como luxo não declararam apenas uma compreensão inadequada das funções intrínsecas de tal prática, mas revelam um compromisso com postulados educacionais onde o aluno é objecto ou unicamente o significante. Não reconhecem a escola como local onde o sujeito deve se significar e tornar-se senhor do seu próprio destino. Não procede identificar como luxo o acto de reconhecimento de uma necessidade original do sujeito: a de participar das manifestações estéticas existentes no mundo e capacidade de estender sua intuição poética, no fazer.»

${ }^{34}$ Cf. Bárbara Vasconcelos de Carvalho (1989), A literatura Infantil. São Paulo, Global Editora, p. 267.

${ }_{35}$ Veja-se Glória Bastos (1999), Literatura Infantil e Juvenil. Lisboa, Universidade Aberta, pp. 207-208.

${ }^{36}$ Cf. Tito Agra Amorim (1995), Encontros de Teatro na Escola - História de um Movimento. Porto, Porto Editora, p. 26. 
remontam aos primórdios da Humanidade! Cidadãos conscientes, revisitemolos pois e, logremos!

$\mathrm{Na}$ opinião de George Steiner ${ }^{37}$,

«[...] Se os jovens ingleses escolhem classificar David Beckham acima de Shakespeare e Darwin na lista de tesouros nacionais, se as instituições culturais, as livrarias e as salas de concertos e teatro lutam pela sobrevivência numa Europa que é fundamentalmente próspera e onde a riqueza nunca falou tão alto, a culpa é muito simplesmente nossa. Assim como o poderia ser a reorientação do ensino secundário e dos meios de comunicação social, por forma a corrigir esse erro. [...] É porventura apenas na Europa que as fundaçôes necessárias de literacia e o sentido da vulnerabilidade trágica da condition humaine poderiam constituir-se como base.

É entre os filhos frequentemente cansados, divididos e confundidos de Atenas e de Jerusalém que poderíamos regressar à conviç̧ão de que "a vida não reflectida" não é efectivamente digna de ser vivida.»

É vital que como europeus reafirmemos certas convicções e arrojos de alma que a americanização do planeta anuviou ${ }^{38}$. A nossa herança é demasiado importante para que a percamos, jovens e seniores.

Caro e admirável Plauto: não morreste, a comédia não chora, o palco jamais será abandonado, e, por conseguinte, o riso, o jogo, a troça, e os ritmos inumeráveis, todos eles gracejam! Espaços e Paisagens de e para SEMPRE!

${ }^{37}$ George Steiner, op. cit., p. 55.

${ }^{38}$ George Steiner, op. cit., p. 53. 